\section{Brassicaceae Cover Crops Affect Seed Germination and Seedling Establishment in Cucurbit Crops}

\author{
Victoria J. Ackroyd ${ }^{1,2}$ and Mathieu Ngouajio ${ }^{1,3,4}$
}

ADDITIONAL INDEX WORDs. allelopathy, bioassay, biofumigation, oilseed radish, mustard, cropping systems, phytotoxicity, stand, vegetable crops

SUMMARY. Field and laboratory bioassay studies were conducted to determine the impact of Brassicaceae cover crops on cucurbit germination percentages and stand counts. A 2-year field study in southwestern Michigan examined the effect of oilseed radish (Raphanus sativus var. oleiferus), oriental mustard (Brassica juncea), and yellow mustard (Sinapis alba) green manures on muskmelon (Cucumis melo Group reticulatus) stand. All three cover crops reduced direct-seeded muskmelon stand count as well as transplant survival. Stand count for direct- seeded muskmelon was greater than $85 \%$ for control and methyl bromide treatments and less than $41 \%$ for cover crop treatments. Oilseed radish had the greatest effect with $0 \%$ muskmelon stand in both years. The use of transplants improved muskmelon stand establishment. However, stand count (less than $45 \%$ to $50 \%$ ) was still unacceptable. In bioassays, muskmelon, cucumber (Cucumis sativus), and honeydew melon (Cucumis melo Group inodorus) seeds were exposed to either non-lyophilized or lyophilized root and shoot aqueous extracts of oilseed radish. Germination percentages and radicle elongation measurements showed both extracts impacted all three crops to varying degrees. Muskmelon germination was least sensitive to the extracts, followed by cucumber, then honeydew. Cucumber and muskmelon root growth was equally inhibited by non-lyophilized shoot extract, while honeydew growth was mildly stimulated at $5 \%$ and $12.5 \%$ concentrations. Overall, nonlyophilized root extract showed stronger inhibition on seed germination than nonlyophilized shoot extract, while the reverse was true of lyophilized extracts. In general, non-lyophilized extracts had far greater impact on germination percentages and radicle elongation than lyophilized extracts. These results suggest species and tissue dependent toxicity of the cover crops as well as differential susceptibility of the cucurbit crops tested. Therefore, a plant-back period longer than the 8 days used in this study should be observed after cover crop incorporation before cucurbit seeding or transplanting.

$\mathrm{T}$ he methyl bromide phase-out was completed in 2005 , and its availability is currently based on critical use exemptions. For production of many vegetables, especially cucurbit crops, methyl bromide alternatives are not available, and growers continue to rely on critical use exemptions. These

This work was partially funded by the U.S. Department of Agriculture Methyl Bromide Transitions Program (Grant no. 2006-51102-03565).

The authors thank Drs. Muraleedharan Nair and Yunbao Liu for their aid with laboratory procedures and equipment and undergraduate assistants Aristarque Djoko, Pamela Nichols, Adam Katlein, Rebekah Struck, and Dr. Guangyao Wang for their assistance in data collection. Grower Ron Eding's donation of oilseed radish biomass was greatly appreciated. We are also grateful to Dave Francis (farm manager) and the crew at the South West Michigan Research and Extension Center for their help with the field work.

${ }^{1}$ Department of Horticulture, Michigan State University, Plant and Soil Sciences Building, East Lansing, MI 48824

${ }^{2}$ Former Graduate Student

${ }^{3}$ Associate Professor

${ }^{4}$ Corresponding author. E-mail: ngouajio@msu.edu. exemptions are unlikely to last forever. For management of soilborne diseases, any practice that is environmentally friendly and economically feasible is likely to be well received by growers, consumers, and the government. Cover crops in the Brassicaceae family (brassica) such as oilseed radish, oriental mustard, and yellow mustard have been shown to decrease plant pathogen populations in the soil (Sarwar et al., 1998). Cover crops in general provide a variety of additional benefits in a production system: they decrease erosion, aid nutrient cycling, preserve soil quality, and suppress weeds (Mutch and Snapp, 2003). Use of brassica species in crop rotations could be one of the practices that may help control soilborne pathogens, while contributing other benefits such as decreased erosion and weed suppression.

Research suggests that brassica cover crops may be phytotoxic to cash crop seeds. Haramoto and Gallandt (2005) determined that brassica cover crops decreased cash crop emergence by $23 \%$ to $34 \%$ and delayed germination $2 \mathrm{~d}$, although their impact was similar to that of other short-season cover crops such as red clover (Trifolium pratense); cash crops tested in the study included carrot (Daucus carota), tomato (Solanum lycopersicum), and cucumber. Laboratory experiments have shown that compounds produced by brassica cover crops can inhibit weed seed germination (Norsworthy and Meehan, 2005a, 2005b; Norsworthy et al., 2006). Studies with black mustard (Brassica nigra) aqueous extracts have shown that extracts inhibit germination and growth of lentil (Lens culinaris) and wild oat (Avena fatua) (Turk and Tawaha, 2002, 2003). Phytotoxicity would typically be a problem in production systems where the cover crop is tilled under and another crop is immediately planted,

\begin{tabular}{llll}
\hline $\begin{array}{l}\text { Units } \\
\text { To convert U.S. to SI, } \\
\text { multiply by }\end{array}$ & U.S. unit & SI unit & $\begin{array}{l}\text { To convert SI to U.S., } \\
\text { multiply by }\end{array}$ \\
\hline 10 & $\%$ & $\mathrm{~g} \cdot \mathrm{L}^{-1}$ & 0.1 \\
0.4047 & $\mathrm{acre}(\mathrm{s})$ & $\mathrm{ha}$ & 2.4711 \\
29.5735 & $\mathrm{fl} \mathrm{oz}$ & $\mathrm{mL}$ & 0.0338 \\
0.3048 & $\mathrm{ft}$ & $\mathrm{m}$ & 3.2808 \\
0.0929 & $\mathrm{ft}^{2}$ & $\mathrm{~m}^{2}$ & 10.7639 \\
3.7854 & $\mathrm{gal}$ & $\mathrm{L}$ & 0.2642 \\
133.6806 & gal/ $\mathrm{ft}^{3}$ & $\mathrm{~L} \cdot \mathrm{m}^{-3}$ & 0.0075 \\
2.54 & inch $(\mathrm{es})$ & $\mathrm{cm}$ & 0.3937 \\
25.4 & inch $(\mathrm{es})$ & $\mathrm{mm}$ & 0.0394 \\
6.4516 & inch & $\mathrm{cm}$ & 0.1550 \\
16.3871 & inch & $\mathrm{cm}$ & 0.0610 \\
0.4536 & $\mathrm{lb}$ & $\mathrm{kg}$ & 2.2046 \\
1.1209 & lb/acre & $\mathrm{kg} \cdot \mathrm{ha}^{-1}$ & 0.8922 \\
28.3495 & $\mathrm{Oz}$ & $\mathrm{g}$ & 0.0353 \\
305.1517 & $\mathrm{oz} / \mathrm{ft}^{2}$ & $\mathrm{~g} \cdot \mathrm{m}^{-2}$ & 0.0033 \\
0.001 & $\mathrm{ppm}$ & $\mathrm{g} \cdot \mathrm{L}^{-1}$ & 1000 \\
$\left({ }^{\circ} \mathrm{F}-32\right) \div 1.8$ & ${ }^{\circ} \mathrm{F}$ & ${ }^{\circ} \mathrm{C}$ & $\left(1.8 \times{ }^{\circ} \mathrm{C}\right)+32$ \\
& & &
\end{tabular}


as in a muskmelon/eggplant (Solanum melongena) short rotation wherein the cover crop is planted in April and tilled under in late May under growing conditions similar to those in Michigan.

Brassica cover crops produce multiple classes of compounds that have allelopathic properties. The primary class of interest is glucosinolates, which when degraded by hydrolysis produce biologically active compounds called isothiocyanates (ITCs) (Kirkegaard and Sarwar, 1998). Some of these glucosinolate by-products are watersoluble, while some are highly volatile (Brown and Morra, 1996). Other compounds from glucosinolate hydrolysis that may be allelopathic are organic cyanides and oxazolidinethione (Brown and Morra, 1996).

Allelopathy is not the only mechanism by which brassica cover crops could impact germination. Cohen and Mazzola (2006) and Hoagland et al. (2008) have demonstrated that some low-glucosinolate canola (Brassica napus) seed meals can change the composition of soil microbe communities, leading to increases in the Pythium populations. Because of their allelopathic effects, brassica cover crops have the potential to be a valuable tool in vegetable cropping systems. However, more information is needed on their impact on cash crops (especially those that are direct-seeded) to ensure they are safe tools to use in vegetable production. The objectives of this study were to quantify the impact of oilseed radish and mustard cover crops on cucurbit crop germination and stand establishment under field conditions and validate field observations with laboratory bioassay studies.

\section{Materials and methods}

Field EXPERIMENTs. This experiment had a randomized complete block design with three replications. Individual plots were $346.5 \mathrm{ft}^{2}(2 \mathrm{l}-\mathrm{ft}$ long by $16.5-\mathrm{ft}$ wide). Treatments were oriental mustard, yellow mustard, oilseed radish, bare soil (- control), and methyl bromide (+ control). For the rest of this paper, the bare soil treatment will be referred to as the control. No cover crop was grown in the control plots, but plastic mulch and drip irrigation were applied as in the other treatments. 'Tilney' yellow mustard, 'Defender' oilseed radish, and 'Forge' oriental mustard were sown at the
Southwest Michigan Research and Extension Center (SWMREC) in Benton Harbor, MI (lat. $-42^{\circ} 7^{\prime} 0^{\prime \prime} \mathrm{N}$, long. $-86^{\circ} 27^{\prime} 15^{\prime \prime} \mathrm{W}$ ), on 4 Apr. 2008 and 1 Apr. 2009. The soil was an Oakville series fine sand transitioning to loamy sand. Cover crops were sown using a seed drill (model 450; John Deere, Moline, IL). In 2008, the seeding rates were $20.0 \mathrm{lb} /$ acre oilseed radish, $7.6 \mathrm{lb} /$ acre oriental mustard, and 9.3 $\mathrm{lb} /$ acre yellow mustard. In 2009 , the seeding rates were $10.0 \mathrm{lb} /$ acre oilseed radish, $6.0 \mathrm{lb} /$ acre oriental mustard, and $8.0 \mathrm{lb} /$ acre yellow mustard. Seeding rates were reduced in 2009 on the basis of seed size and germination rate to achieve maximum biomass production by decreasing intraspecific competition. Cover crops had been planted in these plots in 2007, although detailed data were not collected for that year and are not reported in this paper; treatments remained the same throughout the experiment. Methyl bromide (50:50 mix of methyl bromide and chloropicrin) was applied on 19 May 2008 and 21 May 2009 at 400 lb/acre, and plastic mulch and drip tape were installed at the same time. Cover crops were flail mowed and incorporated into the soil with a rotovator on 3 June 2008 and 4 June 2009 at the flowering stage. Care was taken to avoid cross contamination. Beds were then shaped and covered with plastic mulch; irrigation drip tape was also installed. 'Athena' muskmelon was used as the test crop and planted on 10 June 2008 and 12 June 2009. In 2008, muskmelons were directseeded in four beds, with the two outer rows acting as guard rows. In 2009 , muskmelons were both directseeded (two beds) and transplanted (two beds) to test the effects of the treatments on muskmelon transplants. The muskmelons were reseeded (to replace missing plants) on 25 June 2008 and 25 June 2009 after the last seed emergence evaluation, as is standard practice among growers. In addition to guard rows, there were guard plants ('Earlibrew' honeydew) at the beginning and end of each row. In both years, muskmelons were spaced $3 \mathrm{ft}$ apart within the bed (seven plants per bed, 2640 plants /acre) with $5.5 \mathrm{ft}$ between beds center to center; each bed was $21 \mathrm{ft}$ long. Both years two muskmelon seeds were planted in each hole, and then plants were thinned to seven per bed. Fertigation commenced
3 weeks after planting and occurred once per week. Plants received $1.0 \mathrm{lb} /$ acre of nitrogen per week in the form of a $4 \mathrm{~N}-0 \mathrm{P}-6.6 \mathrm{~K}-2 \mathrm{Ca}$ fertilizer through the drip irrigation system. Irrigation ran three times per week for $1 \mathrm{~h}$ at a time regardless of rainfall amount. Pesticides were applied as per standard grower practices (Bird et al., 2009). Rows were hoed and beds handweeded as necessary.

LABORATORY EXPERIMENTS. Oilseed radish was planted on a commercial farm on 14 Sept. 2009 in Hamilton, MI (lat. $-42^{\circ} 40^{\prime} 39^{\prime \prime} \mathrm{N}$, long. $-86^{\circ} 0^{\prime} 22^{\prime \prime} \mathrm{W}$ ). The soil was a Houghton muck soil with $80 \%$ organic matter. A total of 528 plants were harvested from 15 randomly placed $0.5-\mathrm{m}^{2}$ quadrats on 30 Nov. 2009. Plants were 1 to $2 \mathrm{ft}$ tall and had not yet initiated flower buds. The plants were rinsed with tap water, then with deionized water to remove soil, air-dried for $1 \mathrm{~d}$ at room temperature $\left(23^{\circ} \mathrm{C}\right)$, and weighed. Roots were separated from shoots and processed separately. The tissue was processed in a commercial grade blender (CB-10; Waring Commercial $\AA$, Torrington, CT) with deionized water (1 L to $1 \mathrm{~kg}$ biomass) for 90 to $120 \mathrm{~s}$. The resulting extracts were strained through cheesecloth. Both extracts were then filtered through Whatman no. 4 filter paper (Whatman, Kent, UK). These extracts were referred to as the nonlyophilized extracts. Some of the strained liquids were further centrifuged at $16,210 g_{\mathrm{n}}$ for $10 \mathrm{~min}$ (RC5C; Sorvall ${ }^{\circledR}$ Instruments/DuPont, Wilmington, $\mathrm{DE}$ ), and then the supernatants were freeze-dried using a lyophilizer (FTS Systems, Stone Ridge, NY). The resulting powders were mixed to allow for uniformity and stored at $4{ }^{\circ} \mathrm{C}$ until use. Solutions made with these powders were referred to as lyophilized extracts.

Experiments to test both types of extracts were conducted using a completely randomized design with three replications. Each experiment was conducted three times. Non-lyophilized extract was diluted with deionized water to make solutions of $0 \%$, $5 \%, 12.5 \%, 25 \%, 50 \%$, and $100 \%$ strength. Deionized water was the control. For assays using lyophilized extracts, extracts were dissolved in deionized water to create concentrations of $0,0.25,0.5,1,2,4$, and 8 $\mathrm{g} \cdot \mathrm{L}^{-1}$ by serial dilution of a stock solution containing $8 \mathrm{~g} \cdot \mathrm{L}^{-1}$. Crops 
tested were 'Journey' cucumber, 'Athena' muskmelon, and 'Earlibrew' honeydew. Ten seeds of each crop were placed in $10-\mathrm{cm}$-diameter petri dishes on Whatman no. 4 filter paper, and then $3.0 \mathrm{~mL}$ of each extract dilution was placed into each petri dish. Dishes were sealed with parafilm (Pechiney Plastic Packaging Co., Chicago, IL). Seeds were incubated in a growth chamber (Conviron; Controlled Environments, Winnipeg, $\mathrm{MB}$, Canada) at $21{ }^{\circ} \mathrm{C}$ in the dark for $6 \mathrm{~d}$.

The electrical conductivity (EC) and $\mathrm{pH}$ of the $100 \%$ concentration treatments for non-lyophilized extract, the $8 \mathrm{~g} \cdot \mathrm{L}^{-1}$ lyophilized extract, and deionized water were measured with a $\mathrm{pH} /$ conductivity meter (Horiba D-24; Spectrum Technologies, Plainfield, IL). An experiment was run using deionized water acidified with acetic acid (food grade vinegar for household use) to a $\mathrm{pH}$ of 5.5 to determine if the extracts' acidity was a confounding variable. Three milliliters of vinegar solution were placed in each of four petri dishes containing 10 seeds each; deionized water was the control. Seeds were incubated at $21{ }^{\circ} \mathrm{C}$ for $6 \mathrm{~d}$. As the ECs of water and extracts were similar, no experiment was run to test the possibility of EC being a confounding variable.

FIELD EQUivalent CONCENTRATION ESTIMATES. Field equivalent rates (FERs) (extract concentrations that would typically occur under field conditions) were estimated for both types of extracts. For the non-lyophilized sample, FER was calculated based on area harvested, total fresh biomass, and amount of extract obtained (Table 1). For lyophilized extracts, FER estimates were based on amount of extract produced and harvested area (Table 2). Both estimates rely on the assumptions that the cover crop is incorporated within the top $15 \mathrm{~cm}$ of soil, extracted materials are released simultaneously and immediately into the environment, and $3 \mathrm{~mL}$ of aqueous extract were added to each petri dish (equal to $47 \mathrm{~L}$ of aqueous extract per cubic meter of soil). The equation for FER estimation for lyophilized extract follows Hill (2006):

$$
\mathrm{FER}=E \times P /(A \times D \times W),
$$

where $E$ is total extract dry weight in grams, $P$ is petri dish volume (64 $\left.\mathrm{cm}^{3}\right), A$ is area harvested in square centimeters, $D$ is assumed depth of cover crop incorporation $(15 \mathrm{~cm})$, and $W$ is extract volume added to each petri dish during bioassays $(3 \mathrm{~mL})$ (Hill, 2006). Extracts are likely released over time in the field, not simultaneously as assumed. These estimated FER are thus likely higher than would be found under field conditions.

Data COLleCtion AND ANALYSIS. In the field study, before cover crop incorporation, plant samples were taken from each cover crop treatment, in two areas of $50 \times 50 \mathrm{~cm}$ each. The plants in each sample were counted and dried at $60^{\circ} \mathrm{C}$ until constant weight and dry biomass of entire plants (roots, stems, leaves, and flowers) were determined. Data collection on muskmelons began 2 weeks after planting, with stand counts. Stand counts were taken by tallying the number of seedlings/transplants present in each plot $13 \mathrm{~d}$ after planting. Muskmelon harvests were conducted 21 Aug., 3 Sept., 10 Sept., 17 Sept., and 24 Sept. 2009. Fruit were sorted as either marketable or cull, counted, and weighed according to market standards (U.S. Department of Agriculture, 2008). For laboratory experiments, petri dishes were opened on day 6 , and radicle length and germination rates were measured. Radicle length was measured using a digital caliper (Avenger Products, Boulder City, NV). A seed was considered to have germinated if the radicle length was at least $2 \mathrm{~mm}$.
Field experiment data were analyzed using PROC GLM and ANOVA procedures of SAS (SAS version 9.2; SAS Institute, Cary, NC). Means were separated using Fisher's protected least significant difference using a probability value of 0.05 . Data from 2008 and 2009 were combined when there was no year by treatment interaction. Data from the three runs of laboratory experiments were combined because there were no experiments by treatment interactions.

Data on seed germination and radicle inhibition were fitted to the logistic dose response equation (Hill et al., 2006, 2007):

$$
\mathrm{RL}(X)=a+\frac{b}{\left(1+\left(\frac{X}{c}\right)^{d}\right)},
$$

where $\mathrm{RL}(X)$ is the radicle length (as a percent of the control) at extract concentration $X$, and $a, b, c$, and $d$ are regression coefficients. A separate model was used to describe the responses when a strong initial stimulation was observed (Hill et al., 2006, 2007; Norsworthy and Meehan, 2005a, 2005b). The model had the following form:

$$
\mathrm{RL}(X)=a \exp \left(-0.5[\{X-b\} / c]^{2}\right),
$$

where $\mathrm{RL}(X)$ is radicle length (as a percent of the control) at extract concentration $X, a$ is maximum radicle length (as a percent of the control), $b$ is extract concentration at maximum length, and $c$ is a constant. All regression analyses were conducted with TableCurve 2D® (version 4; Systat Software, San Jose, CA).

\section{Results}

FIELD EXPERIMENTS. Low temperatures were comparable in 2008 and 2009, but 2009 experienced cooler daily maximum temperatures (data not shown). Total rainfall from April to August was $291 \mathrm{~mm}$ in 2008

\begin{tabular}{|c|c|c|c|c|c|c|c|}
\hline \multirow{2}{*}{$\begin{array}{l}\text { Extract } \\
\text { source }\end{array}$} & \multirow{2}{*}{$\begin{array}{c}\text { Area } \\
\text { harvested } \\
\left(\mathrm{m}^{2}\right)^{\mathrm{z}}\end{array}$} & \multirow{2}{*}{$\begin{array}{c}\text { Total fresh } \\
\text { biomass }(\mathrm{kg})^{\mathrm{z}}\end{array}$} & \multirow{2}{*}{$\begin{array}{l}\text { Fresh wt } \\
\left(\mathrm{kg} \cdot \mathrm{ha} \mathrm{a}^{-1}\right)^{\mathrm{z}}\end{array}$} & \multirow{2}{*}{$\begin{array}{c}\text { Total } \\
\text { deionized } \\
\text { water }(L)^{z}\end{array}$} & \multicolumn{2}{|c|}{ Extract amount $^{\mathrm{y}}$} & \multirow{2}{*}{$\begin{array}{c}\text { Extract field } \\
\text { rates }(\mathrm{mL} / \text { petri dish })^{\mathrm{x}}\end{array}$} \\
\hline & & & & & Cheesecloth (L) & Filter paper $(\mathrm{L})$ & \\
\hline Roots & 7.5 & 4.4 & 5,867 & 4.4 & 5.9 & 3.4 & 0.2 \\
\hline Shoots & 6.4 & 12.8 & 19,969 & 12.8 & 13.9 & 10.1 & 0.7 \\
\hline
\end{tabular}

Table 1. Oilseed radish harvest and non-lyophilized aqueous extract data and corresponding field equivalent rates (FERs). The ratio of deionized water to biomass was 1:1 (vol:wt).

${ }^{\mathrm{z}} 1 \mathrm{~m}^{2}=10.7639 \mathrm{ft}^{2}, \mathrm{l} \mathrm{kg}=2.2046 \mathrm{lb}, \mathrm{l} \mathrm{kg} \cdot \mathrm{ha}^{-1}=0.8922 \mathrm{lb} /$ acre, $\mathrm{l} \mathrm{L}=0.2642 \mathrm{gal}$.

yAmount obtained after filtration through a cheesecloth or filter paper; $1 \mathrm{~mL}=0.0338 \mathrm{fl} \mathrm{oz}$.

${ }^{x}$ FER represents the maximum concentration assuming that the cover crop is incorporated $15 \mathrm{~cm}(5.9$ inches) deep and that all allelochemicals are released at the same time. 
and $487 \mathrm{~mm}$ in 2009 compared with the 8 -year average of $390 \mathrm{~mm}$. Rainfall distribution was relatively uniform during those months. In 2008, rainfall amounts were $45,58,59,92,36$, and $293 \mathrm{~mm}$ for April, May, June, July, August, and September, respectively. The majority of the rainfall in September came at the end of the month, after the last harvest. In 2009, rainfall amounts were $105,52,114,104,112$, and $24 \mathrm{~mm}$ for April, May, June, July, August, and September, respectively.

COVER CROP BIOMASS PRODUCTION. Oilseed radish produced the most biomass in $2008\left(6086 \mathrm{~kg} \cdot \mathrm{ha}^{-1}\right)$ followed by oriental mustard and yellow mustard with 3641 and 3487 $\mathrm{kg} \cdot \mathrm{ha}^{-1}$, respectively. In 2009 , the amount of dry biomass produced by the cover crops was similar and was 4173,2843 , and $3000 \mathrm{~kg} \cdot \mathrm{ha}^{-1}$ for oilseed radish, oriental mustard, and yellow mustard, respectively. There was more rain in Apr. 2009 than Apr. 2008, which likely explained the higher estimated biomass weights for all three cover crops in 2009.

CASH CROP STAND ESTABLISHMENT, TRANSPLANT SURVIVAL, AND YIELD. Muskmelon stand varied with year, but within individual years, the impact of the treatments was consistent (Table 3 ). In 2008, plots in methyl bromide and control treatments had $100 \%$ stand count. These values differed significantly from those in yellow mustard treatment $(40.5 \%)$, which in turn differed significantly from those in oriental mustard $(11.9 \%)$ and oilseed radish $(0 \%)$ treatments. In 2009, the pattern was similar. Control and methyl bromide treatments had stand counts of $88.1 \%$ and $85.7 \%$, respectively. The oilseed radish, oriental mustard, and yellow mustard treatments had stand counts of $0 \%, 1.2 \%$, and $2.4 \%$; these values differed significantly from those in other treatments. In 2009, plots were also planted with muskmelon transplants. The survival rate in methyl bromide and control treatments was almost $100 \%$ in contrast to maximum survival rates of only $45 \%$ to $50 \%$ in the cover crop treatments (Table 3 ).

Total and marketable fruit weights were similar among treatments for direct-seeded muskmelon (Table 4). Similar results were observed for marketable fruit number. Total fruit number in direct-seeded melon was greatest

Table 2. Oilseed radish harvest and lyophilized extract data and corresponding field equivalent rates for bioassay studies using 'Athena' muskmelon.

\begin{tabular}{lcccccc}
\hline & & & & \multicolumn{2}{c}{ Ratios } & \\
\cline { 5 - 6 } $\begin{array}{l}\text { Extract } \\
\text { source }\end{array}$ & $\begin{array}{c}\text { Area } \\
\text { harvested } \\
\left(\mathbf{m}^{2}\right)^{\mathbf{z}}\end{array}$ & $\begin{array}{c}\text { Total fresh } \\
\text { biomass } \\
(\mathbf{k g})^{\mathbf{z}}\end{array}$ & $\begin{array}{c}\text { Extract } \\
\text { dry } \\
\mathbf{w t}(\mathbf{g})^{\mathbf{z}}\end{array}$ & $\begin{array}{c}\text { Extract/area } \\
\text { harvested } \\
\left(\mathbf{g} \cdot \mathbf{m}^{-2}\right)^{\mathbf{z}}\end{array}$ & $\begin{array}{c}\text { Extract/fresh } \\
\text { biomass } \\
\left(\mathbf{g} \cdot \mathbf{k g}^{-1}\right)^{\mathbf{z}}\end{array}$ & $\begin{array}{c}\text { Extract } \\
\text { field rates } \\
\left(\mathbf{g} \cdot \mathbf{L}^{-1}\right)^{\mathbf{y}}\end{array}$ \\
\hline Roots & 3.9 & 2.3 & 110.0 & 28.1 & 48.0 & 4.0 \\
Shoots & 2.9 & 5.8 & 181.0 & 62.4 & 31.3 & 8.9 \\
\hline
\end{tabular}

${ }^{2} 1 \mathrm{~m}^{2}=10.7639 \mathrm{ft}^{2}, \mathrm{l} \mathrm{kg}=2.2046 \mathrm{lb}, \mathrm{lg}=0.0353 \mathrm{oz}, \mathrm{lg} \cdot \mathrm{m}^{-2}=0.0033 \mathrm{oz} / \mathrm{ft}^{2}, \mathrm{l} \mathrm{g} \cdot \mathrm{kg}^{-1}=0.1 \%$.

"Estimated extract field equivalent rate (FER) calculated using the following equation: $\mathrm{FER}=E \times P / A \times D \times W$, where FER is estimated field equivalent rate, $E$ is total extract dry weight in grams, $P$ is petri dish volume $\left[64 \mathrm{~cm}^{3}\right.$ (3.9 inch $\left.^{3}\right)$ ] $A$ is area harvested in square centimeters, $D$ is assumed depth of cover crop incorporation in centimeters, and $W$ is extract volume added to each petri dish during bioassays $(3 \mathrm{~mL})$ (Hill, 2006). Field equivalent rate represents the maximum concentration assuming that the cover crop is incorporated $15 \mathrm{~cm}(5.9$ inches) deep and that all allelochemicals are released at the same time; $1 \mathrm{~g} \cdot \mathrm{L}^{-1}=1000 \mathrm{ppm}$.

Table 3. 'Athena' muskmelon stand as affected by oilseed radish and mustard cover crops in 2008 and 2009 in Benton Harbor, MI. ${ }^{\mathrm{z}}$

\begin{tabular}{lccc}
\hline & \multicolumn{3}{c}{ Muskmelon stand (\%) } \\
\cline { 2 - 3 } Treatment & \multicolumn{2}{c}{ Direct-seed } & Transplant \\
\cline { 2 - 3 } & $\mathbf{2 0 0 8}$ & $\mathbf{2 0 0 9}$ & $97.6 \mathrm{a}$ \\
Methyl bromide & $100.0 \mathrm{a}^{\mathrm{y}}$ & $85.7 \mathrm{ab}$ & $50.0 \mathrm{~b}$ \\
Oilseed radish & $0.0 \mathrm{c}$ & $0.0 \mathrm{c}$ & $45.2 \mathrm{~b}$ \\
Oriental mustard & $11.9 \mathrm{c}$ & $1.2 \mathrm{c}$ & $45.2 \mathrm{~b}$ \\
Yellow mustard & $40.5 \mathrm{~b}$ & $2.4 \mathrm{c}$ & $100.0 \mathrm{a}$ \\
Control & $100.0 \mathrm{a}$ & $88.1 \mathrm{a}$ & \\
\hline
\end{tabular}

${ }^{2}$ Muskmelons were direct-seeded on 10 June 2008 and 12 June 2009 or transplanted on 12 June 2009. Stand counts were assessed on 23 June 2008 and 25 June 2009.

${ }^{\mathrm{y}}$ Means within a column followed by the same letter are not significantly different via Fisher's protected least significant difference using a probability value of 0.05 . in methyl bromide and control treatments. In transplanted muskmelon plots, there were significant differences in marketable number, total number, and total weight of fruit (Table 4). Methyl bromide and oilseed radish plots produced 12,580 and 13,046 marketable fruit per plot compared with yellow mustard plots, which produced significantly fewer (9040 marketable fruit per plot). Plants in methyl bromide, oilseed radish, and control plots produced 17,984 to 20,500 fruit total, while those in the mustard treatments produced 9598 to 13,698 fruit. There was no significant difference in marketable yields although total yield was significantly higher in oilseed radish plots.

LABORATORY EXPERIMENTS. OIlseed radish produced an estimated three times more shoot tissue than root tissue (Table 1). The harvest netted $4.4 \mathrm{~kg}$ of root tissue and 12.8 $\mathrm{kg}$ of shoot tissue. The large proportion of shoot to root tissue was due to the taproots not being well developed at cover crop sampling. When macerated in a $1: 1$ ratio of biomass: deionized water and strained through cheesecloth, the results were 5.9 and $13.9 \mathrm{~L}$ of root and shoot tissue aqueous extract, respectively. This extract was then filtered through filter paper, for a total of $3.43 \mathrm{~L}$ of nonlyophilized root aqueous extract and 10.1 L of non-lyophilized shoot aqueous extract. Lyophilized root and shoot extracts yielded 110.0 and $181.0 \mathrm{~g}$ of dry powder from 2.3 and $5.8 \mathrm{~kg}$ of fresh biomass, respectively (Table 2). The FER for non-lyophilized extract was 0.2 and $0.7 \mathrm{~mL} /$ petri dish for root and shoot extracts, respectively (Table 1). Lyophilized extract FER was 4.00 and $8.9 \mathrm{~g} \cdot \mathrm{L}^{-1}$ for root and shoot extracts, respectively (Table 2).

The $\mathrm{pH}$ of the deionized water was 8.2 , while that of root and shoot extracts was 6.0 and 5.8 , respectively. The EC of the deionized water, root extract, and shoot extract was 28.1, 29.5 , and $25.4 \mathrm{mV}$, respectively. An experiment was conducted using an acetic acid solution with a $\mathrm{pH}$ of 5.4; germination for muskmelon seeds in this treatment was $97.5 \%(\mathrm{SD}=5 \%)$, while that of seeds in the deionized water control was $100 \%$ ( $S D=0 \%$ ). Average radicle length in the acetic acid treatment was $35.7 \mathrm{~mm}$, while in the control, it was $36.3 \mathrm{~mm}$. 
Table 4. Direct-seeded (DS) and transplanted (T) 'Athena' muskmelon marketable and total yield as affected by oilseed radish and mustard cover crops in 2009 in Benton Harbor, MI. ${ }^{\mathrm{z}}$

\begin{tabular}{|c|c|c|c|c|c|c|c|c|}
\hline \multirow[b]{2}{*}{ Treatment } & \multicolumn{2}{|c|}{ Marketable fruit (no./ha) $)^{y}$} & \multicolumn{2}{|c|}{ Total fruit (no./ha) } & \multicolumn{2}{|c|}{ Marketable yield $\left(\mathrm{kg} \cdot \mathrm{ha}^{-1}\right)^{\mathrm{x}}$} & \multicolumn{2}{|c|}{ Total yield $\left(\mathrm{kg} \cdot \mathrm{ha}^{-1}\right)$} \\
\hline & DS & $\mathrm{T}$ & DS & $\mathrm{T}$ & DS & $\mathrm{T}$ & DS & $\mathrm{T}$ \\
\hline Methyl bromide & 6,058 & $12,580 \mathrm{ab}^{\mathrm{w}}$ & $14,630 \mathrm{a}$ & 18,358 a & 11,368 & 23,016 & 20,966 & $29,260 \mathrm{~b}$ \\
\hline Oriental mustard & 6,058 & $9,598 \mathrm{bc}$ & $9,598 \mathrm{bc}$ & $12,766 \mathrm{~b}$ & 15,282 & 21,992 & 19,570 & $25,532 \mathrm{~b}$ \\
\hline Yellow mustard & 5,870 & $9,040 \mathrm{c}$ & $8,108 \mathrm{c}$ & $13,698 \mathrm{~b}$ & 13,326 & 18,916 & 16,866 & $25,532 \mathrm{~b}$ \\
\hline Control & 8,108 & $11,368 \mathrm{a}$ & $13,326 \mathrm{a}$ & $17,984 \mathrm{a}$ & 16,680 & 21,620 & 20,314 & $28,142 \mathrm{~b}$ \\
\hline
\end{tabular}

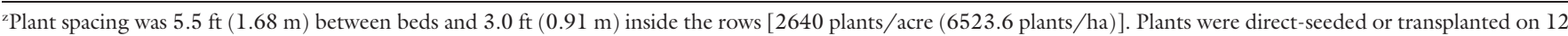
June 2009.

yFruit were sorted into marketable fruit and fruit that failed to meet the standards, that is, culls (U.S. Department of Agriculture, 2008 ); 1 fruit/ha $=0.4047$ fruit/acre.

${ }^{\mathrm{x}} \mathrm{l} \mathrm{kg} \cdot \mathrm{ha}^{-1}=0.8922 \mathrm{lb} / \mathrm{acre}$.

${ }^{\text {w}}$ Means within a column followed by the same letter are not significantly different via Fisher's protected least significant difference using a probability value of 0.05 .

Germination. Both root and shoot non-lyophilized aqueous extracts significantly reduced germination of honeydew, muskmelon, and cucumber (Fig. 1). As concentration of both extracts increased from $0 \%$ to $100 \%$, inhibition became more pronounced. Whereas $100 \%$ of seeds germinated at $0 \%$ extract concentration, at $100 \%$ extract concentration germination rates ranged from $0 \%$ to $3.4 \%$. Muskmelon germination was unaffected by non-lyophilized root and shoot extracts of oilseed radish at low concentrations. Lyophilized extract had varying impacts on the crops (Fig. 1). There were no differences in muskmelon germination rates across treatments for both extracts. However, as concentration increased, germination of both cucumber and honeydew seeds decreased. Germination remained above $20 \%$ at the highest concentrations of the extracts. As extract concentrations increased, honeydew had a more rapid drop in germination than cucumber.

RADICLE LENGTH. Both root and shoot non-lyophilized aqueous extracts of oilseed radish affected radicle elongation of cucumber, honeydew, and muskmelon (Fig. 2). As extract concentration increased, impact on radicle length became more pronounced. At the $50 \%$ extract concentration, radicle growth was almost completely inhibited. Surprisingly, concentrations of $5 \%$ and $12.5 \%$ of both root and shoot non-lyophilized extracts stimulated root growth in honeydew. As with germination rates, lyophilized extracts had a less pronounced impact on radicle elongation than non-lyophilized extracts (Fig. 2 ). Except for muskmelon, none of the crops were affected by lyophilized shoot extracts, especially for rates
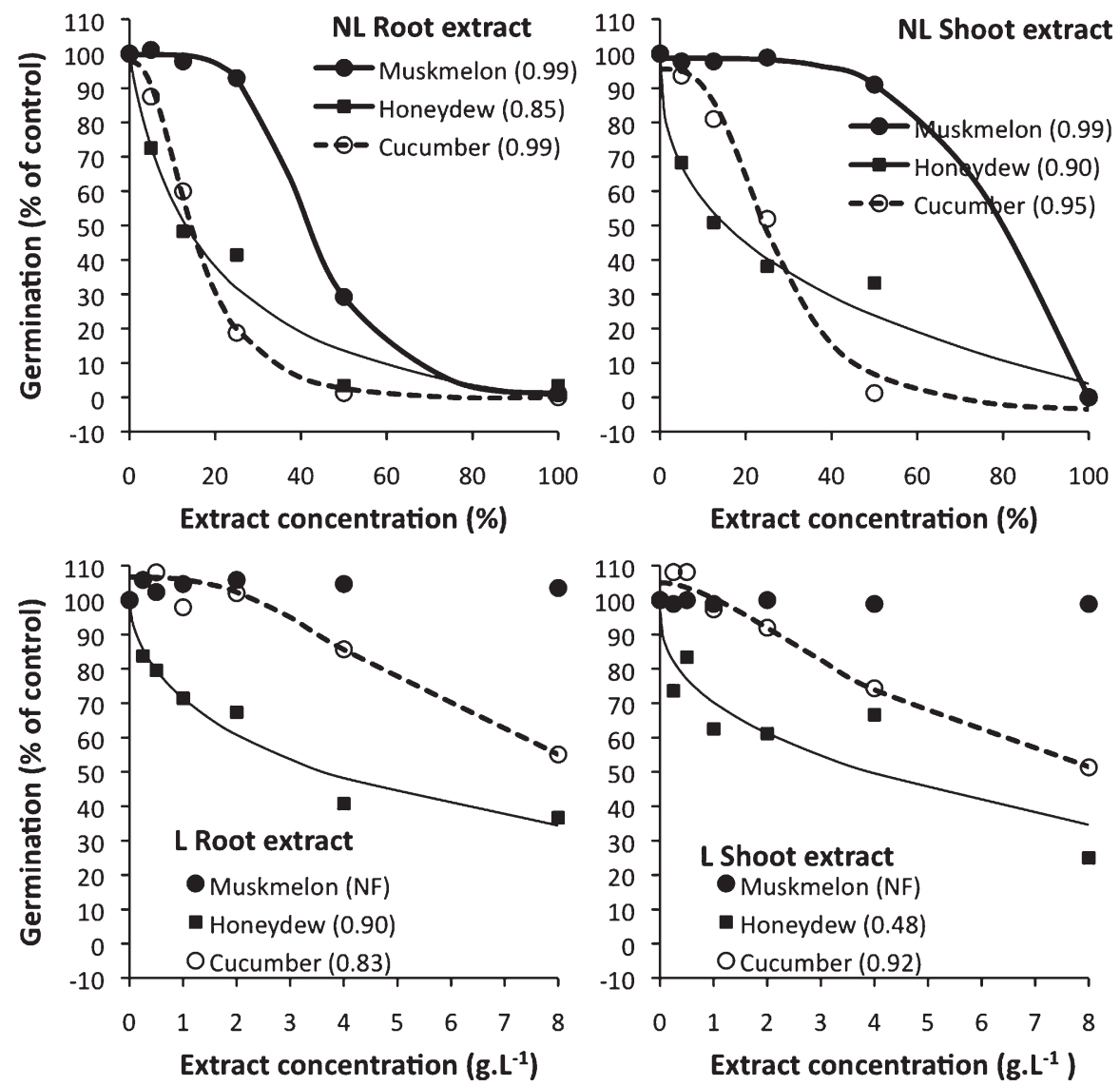

Fig. 1. Normalized germination percentages of three cucurbit crops exposed to six extract concentrations of non-lyophilized (NL) and lyophilized (L) oilseed radish root and shoot aqueous extracts. Germination was expressed as a percentage of the value obtained for the control to allow for comparison among crops. Each percentage is the mean of three experimental runs, each consisting of three replications of 10 seeds each. The regression model is presented in Eq. [2]. $R^{2}$ values are indicated in parentheses with NF meaning that the data did not fit the regression models; $1 \mathrm{~g} \cdot \mathrm{L}^{-1}=1000 \mathrm{ppm}$.

lower than $8 \mathrm{~g} \cdot \mathrm{L}^{-1}$. In lyophilized root extract treatments, however, as concentration increased, root length generally decreased (Fig. 2).

\section{Discussion}

In field studies, the cover crops significantly reduced muskmelon emergence in 2008 and 2009. Brassica cover crops have been shown to be allelopathic in laboratory experiments (Bialy et al., 1990; Brown and Morra, 1996; Mason-Sedun and Jessop, 1988; Oleszek, 1987; Turk and Tawaha, 2002, 2003). Cover crops have also been shown to decrease cash 

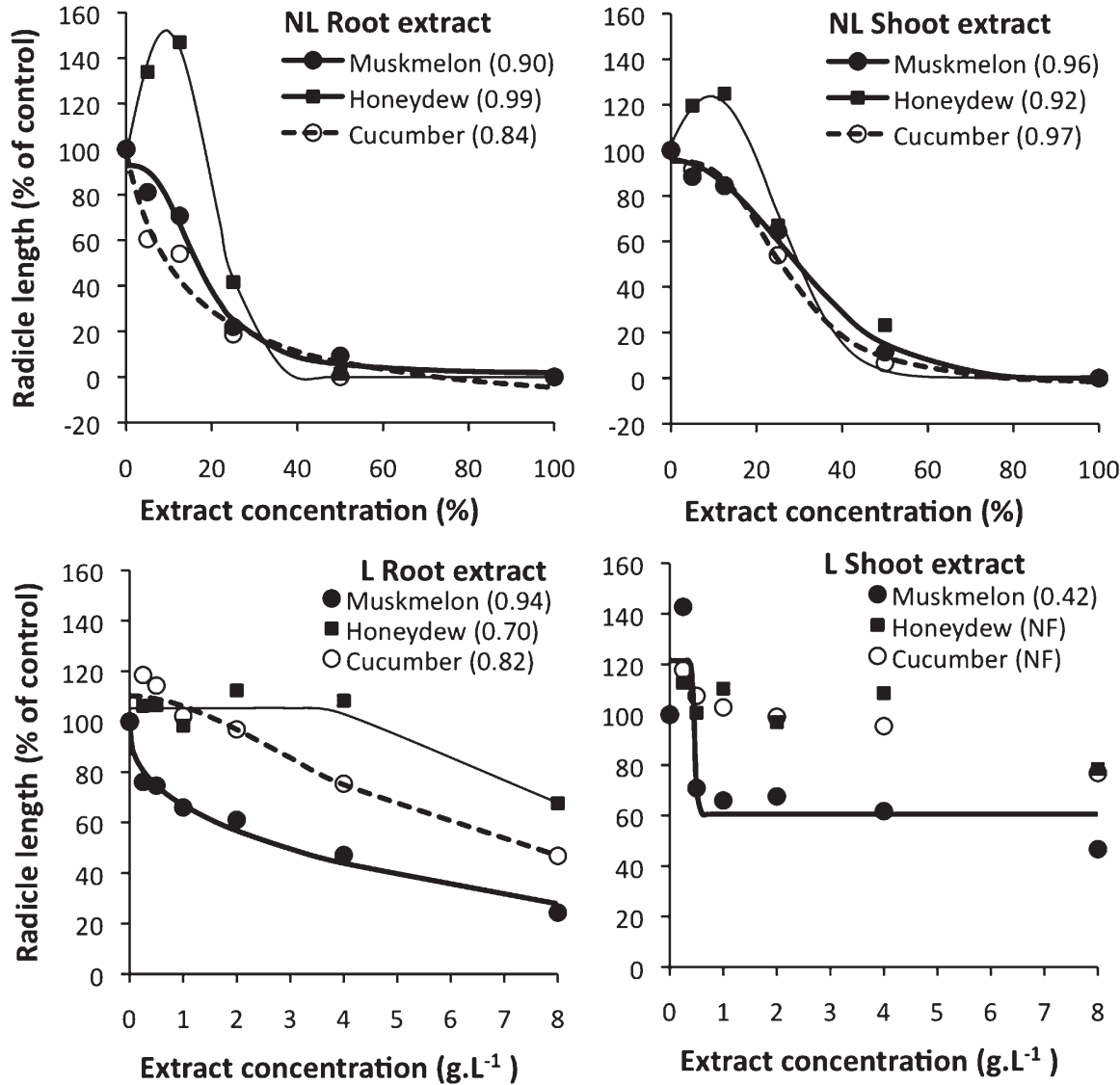

Fig. 2. Radicle lengths of cucurbits exposed to six concentrations of oilseed radish non-lyophilized (NL) and lyophilized (L) root and shoot aqueous extracts. Radicle length was expressed as a percentage of the value obtained for the control to allow for comparison among crops. Each value is the mean of three experimental runs, each consisting of three replications of 10 seeds each. Means were calculated using the number of seeds germinated, not the number of seeds tested. The regression model is presented in Eq. [2]. For responses with initial stimulation (honeydew non-lyophilized extracts), Eq. [3] was used. $\mathrm{R}^{2}$ values are indicated in parentheses with NF meaning the data did not fit the regression models; $1 \mathrm{~g} \cdot \mathrm{L}^{-1}=1000 \mathrm{ppm}$.

crop and weed stand counts in the field (Haramoto and Gallandt, 2005). In addition to the above, brassica cover crops have been implicated in altering soil microbial population levels and structures and encouraging the growth of Pythium populations (Mazzola et al., 2001). Pythium is a common cause of damping-off, which would also explain the decreased stand counts in the cover crop treatments. Mazzola et al. (2001) reported that the effect on cash crops varies by brassica species and that damage may be attributed to allelopathy, microbial population changes, or a combination of the two depending on the cover crop. Allelopathy and increased Pythium populations could also explain decreased survival of transplanted muskmelon. While Pythium impacts many crops, plants have been shown to vary in their vulnerability to brassica cover crops (Norsworthy et al., 2006; Oleszek, 1987). While this work did not test for the presence of Pythium in the experiment, it is likely that allelopathy played a major role in the low emergence of muskmelon. In this study, muskmelon was sown (or transplanted) 7-8 d after cover crop incorporation. The plant-back period was likely not long enough to avoid phytotoxicity from the decomposing residue or chemicals produced during glucosinolate hydrolysis. All seeds that were planted on 25 June (both years) were unaffected, further supporting the hypothesis of allelopathy. Unfortunately, this date is relatively late for muskmelon production in Michigan as late planted plants would not have enough time for full yield before cool weather and frost.

The oilseed radish and mustard cover crops had varying impacts on muskmelon yield. In general, plants in control and methyl bromide treatments produced higher fruit number and fruit weights than those in the cover crop treatments. Of the three cover crops, oilseed radish had the least effect: transplanted plants in this treatment produced more marketable fruit than in non-control and nonmethyl bromide treatments and also the largest total fruit weight of any of the treatments. Yellow mustard arguably had the most effect: plants in this treatment routinely produced the least amount of fruit, both in number and in total weight. There was no significant difference among treatments in the number or marketable fruit weight and total fruit weight produced by direct-seeded muskmelon plants. Plants in the yellow mustard, oilseed radish, and oriental mustard treatments produced significantly less total fruit (number) than those in methyl bromide and control treatments.

The field experiment results indicated poor stand establishment that suggested a need for a laboratory experiment to further investigate the allelopathic potential of brassica on cucurbit seed germination. The amount of oilseed radish biomass harvested for the laboratory experiment was not as large as it would have been when the plants are fully mature and beginning to flower (M. Ngouajio, unpublished data). Yield was about $5866 \mathrm{~kg} \cdot \mathrm{ha}^{-1}$ of fresh root tissue and $19,968 \mathrm{~kg} \cdot \mathrm{ha}^{-1}$ of fresh shoot tissue. This is important because oilseed radish is usually tilled under after flower initiation but before seed set. Based on the above results, estimated field extract rates are likely underestimations of what would happen in a normal situation where the cover crop is allowed to grow until the flowering stage. Allelochemical concentrations may also differ with cover crop stage of development.

Turk and Tawaha $(2002,2003)$ found stronger concentrations of black mustard aqueous extracts were more inhibitory to lentil and wild oat seed germination and seedling growth. The estimated field rate of root tissue $(0.2$ $\mathrm{mL}$ or $6.7 \%$ of the non-lyophilized full strength solution) falls between the $5 \%$ and $12.5 \%$ experimental treatments; at these field extract rates, germination inhibition was observed in cucumber and honeydew and radicle elongation was inhibited in muskmelon and 
cucumber. Shoot tissue estimated field rate $(0.7 \mathrm{~mL}$ or $22.3 \%$ of nonlyophilized full solution strength) falls between the $12.5 \%$ and $25 \%$ treatments; germination inhibition was again observed in honeydew and cucumber at these rates, as was radicle elongation inhibition in cucumber. Therefore, while many of the nonlyophilized extract treatments were more concentrated than the field rate equivalent, effects were still seen at rates near the field rate equivalent and the stronger concentrations help offset the smaller original biomass harvest (had the harvest been of normal size and at the normal time, the field extract rate would naturally have been higher than it was).

The laboratory conditions differ from field conditions in that in the field, organic matter would degrade slowly and water soluble compounds would be released over time. Also, because of soil dynamics, seeds would likely not come into contact with such concentrated volumes of water soluble compounds. Compounds would be mixed with soil and other chemicals in the soil, further diluting them and thus leading to less effect on seed germination. In addition, organic matter and clay in soil can act as buffers (Hoagland et al., 2008). However, the severe muskmelon stand reduction observed in field experiment strongly suggests that allelochemicals from brassica cover crops can cause significant seed germination inhibition in vivo. Further tests ruled out the effects of EC and $\mathrm{pH}$ as contributing factors in the effect of the cover crop extracts on seed germination and radicle growth.

The inhibition of seed germination and radicle elongation was more pronounced when lyophilized extracts were used. Non-lyophilized root aqueous extract appeared to inhibit germination more than shoot aqueous extract. The lyophilized shoot extract more consistently inhibited germination than the root extract. The observation that non-lyophilized root extracts are more potent than shoot extracts is in contrast with the findings of the Brown and Morra (1996) report, which indicates that water soluble compounds from canola leaves and stems inhibited lettuce (Lactuca sativa) seed germination, whereas those from roots merely delayed seed germination. It is also in contrast with the work of Turk and Tawaha (2002, 2003), which determined that black mustard leaf extracts tended to be more toxic than extracts from other plant parts including roots and stems. However, Brown and Morra (1996) reported that volatile compounds from canola roots inhibited lettuce seed germination more than those from stems and leaves. Brassica species vary in their chemical profiles (Kirkegaard and Sarwar, 1998), and these concentrations of chemicals vary depending on the crop involved (Brown and Morra, 1996).

Non-lyophilized root and shoot aqueous extracts inhibited radicle elongation except root extract on honeydew; as the root extract strength increased so did level of inhibition. Honeydew roots were stimulated at $5 \%$ and $12.5 \%$ extract concentrations. Stimulation of plant growth by low rates of brassica residue has been previously reported (Mason-Sedun and Jessop, 1988), which may explain our observation with the low concentrations of extract. Oleszek (1987) stated the impact of brassica cover crops varies depending on the cover crop and the cash crop, perhaps explaining why honeydew growth was stimulated while muskmelon and cucumber growth was inhibited.

As with germination rates, crop root elongation was less sensitive to lyophilized extracts than non-lyophilized extracts. Differences in potency between lyophilized and non-lyophilized extracts probably were due to varying levels of volatile vs. water soluble compounds. While it is likely that both types of compounds have inhibitory effects, volatile compounds (specifically ITCs) are generally believed to be the major cause behind biological activity such as germination inhibition and pathogen disruption in brassica species. The major ITCs found in oilseed radish include 4-methylthiobutyl and 3-indolylmethyl (Kjaer et al., 1978; Sang et al., 1984). Lyophilized extracts likely contained less of these highly active compounds and thus were generally less potent.

\section{Conclusions}

The results suggest that for muskmelon production under Michigan growing conditions, spring-planted oilseed radish and mustard cover crops will not fit well into the cropping system. Cover crop residue will typically require more time to release phytotoxic compounds before cash crop planting. However, the growing season is short for a warm season crop like muskmelon. As a consequence, the use of spring-seeded oilseed radish or mustard cover crops could lead to yield or revenue loss if the plantback period is too short. An alternative to spring planting of the cover crops could be late-summer or fall planting in preparation for muskmelon production the following summer. Such a strategy has shown positive results in celery (Apium graveolens) and onion (Allium cepa) production in organic soil (Wang et al., 2010).

\section{Literature cited}

Bialy, Z., W. Oleszek, J. Lewis, and G.R. Fenwick. 1990. Allelopathic potential of glucosinolates (mustard oil glycosides) and their degradation products against wheat. Plant Soil 129:277-281.

Bird, G., B. Bishop, M. Hausbeck, L.J. Jess, W. Kirk, W. Pett, and F. Warner. 2009. Insect, disease and nematode control for commercial vegetables. Michigan State Univ. Ext. Bul. E 312.

Brown, P.D. and M.J. Morra. 1996. Hydrolysis products of glucosinolates in Brassica napus tissues as inhibitors of seed germination. Plant Soil 181:307-316.

Cohen, M.F. and M. Mazzola. 2006. Resident bacteria, nitric oxide emission and particle size modulate the effect of Brassica napus seed meal on disease incited by Rhizoctonia solani and Pythium spp. Plant Soil 286:75-86.

Haramoto, E.R. and E.R. Gallandt. 2005. Brassica cover cropping: I. Effects on weed and crop establishment. Weed Sci. 53:695-701.

Hill, E.C. 2006. Allelopathic effects of hairy vetch (Vicia villosa) and cowpea (Vigna unguiculata) on weed and vegetable crops. MS Thesis, Michigan State Univ, East Lansing.

Hill, E.C., M. Ngouajio, and M.G. Nair. 2006. Differential response of weeds and vegetable crops to aqueous extracts of hairy vetch and cowpea. HortScience 41:695-700

Hill, E.C., M. Ngouajio, and M.G. Nair. 2007. Allelopathic potential of hairy vetch (Vicia villosa) and cowpea (Vigna unguiculata) methanol and ethyl acetate extracts on weeds and vegetables. Weed Technol. 21:437-444.

Hoagland, L., L. Carpenter-Boggs, J. Reganold, and M. Mazzola. 2008. Role of native soil biology in Brassicaceae seed 
meal induced weed suppression. Soil Biol. Biochem. 40:689-1697.

Kirkegaard, J.A. and M. Sarwar. 1998. Biofumigation potential of brassicas I. Variation in glucosinolate profiles of diverse field-grown brassicas. Plant Soil 201:71-89.

Kjaer, A., J.O. Madsen, Y. Maeda, Y. Ozawa, and Y. Uda. 1978. Volatiles in distillates of fresh radish of Japanese and Kenyan origin. Agr. Biol. Chem. 42:1715-1721.

Mason-Sedun, W. and R.S. Jessop. 1988. Differential phytotoxicity among species and cultivars of the genus Brassica to wheat II. Activity and persistence of watersoluble phytotoxins from residues of the genus. Plant Soil 107:69-80.

Mazzola, M., D.M. Granatstein, D.C. Elfving, and K. Mullinix. 2001. Suppression of specific apple root pathogens by Brassica napus seed meal amendment regardless of glucosinolate content. Phytopathology 91:673-679.

Mutch, D.R. and S. Snapp. 2003. Cover crop choices for Michigan. Michigan State Univ. Ext. Bul. E 2884. 2 Feb. 2010. <http://www.covercrops.msu.edu/ pdf_files/ext_bul_E2884.pdf>.

Norsworthy, J.K., M.S. Malik, P. Jha, and M.J. Oliveira. 2006. Effects of isothiocyanates on purple nutsedge (Cyperus rotundus L.) and yellow nutsedge (Cyperus esculentus L.). Weed Biol. Manage. 6:131-138.

Norsworthy, J.K. and J.T. Meehan. 2005a. Herbicidal activity of eight isothiocyanates on texas panicum (Panicum texanum), large crabgrass (Digitaria sanguinalis), and sicklepod (Senna obtusifolia). Weed Sci. 53:515-520.

Norsworthy, J.K. and J.T. Meehan. 2005 b. Use of isothiocyanates for suppression of palmer amaranth (Amaranthus palmeri), pitted morninglory (Ipomoea lacunosa), and yellow nutsedge (Cyperus esculentus). Weed Sci. 53:884890.

Oleszek, W. 1987. Allelopathic effects of volatiles from some Cruciferae species on lettuce, barnyard grass, and wheat growth. Plant Soil 102:271-273.

Sang, J.P., I.R. Minchinton, P.K. Johnstone, and R.J.W. Truscott. 1984. Glucosinolate profiles in the seed, root, and leaf tissue of cabbage, mustard, rapeseed, radish, and swede. Can. J. Plant Sci. 64:77-93.

Sarwar, M., J.A. Kirkegaard, P.T.W. Wong, and J.M. Desmarchelier. 1998. Biofumigation potential of brassicas III. In vitro toxicity of isothiocyanates to soil-borne fungal pathogens. Plant Soil 201:103-112.

Turk, M.A. and A.M. Tawaha. 2002. Inhibitory effects of aqueous extracts of black mustard on germination and growth of lentil. Pakistan J. Agron. 1:28-30.

Turk, M.A. and A.M. Tawaha. 2003. Allelopathic effect of black mustard (Brassica nigra L.) on germination and growth of wild oat (Avena fatua L.). Crop Prot. 22:673-677.

U.S. Department of Agriculture. 2008. United States standards for grades of cantaloupes. 21 Feb. 2010. <http://www.ams. usda.gov/AMSv1.0/getfile?dDocName= STELPRDC5050255>.

Wang, G., M. Ngouajio, and K.S. Charles. 2010. Brassica biofumigants improve onion (Allium cepa L.) and celery (Apium graveolens) production systems. J. Sustain. Agr. 34:2-14. 